\title{
ANALISIS ORIENTASI SUDUT SERAT DAN JUMLAH LAMINA SERAT TERHADAP KEKUATAN LELAH (FATIQUE) LAMINATED COMPOSITE
}

\author{
Wirawan $^{1}$, Edy Purwanto ${ }^{2}$, Agus Hariyono ${ }^{3}$ \\ Jurusan Teknik Mesin, Politeknik Negeri Malang \\ wirawan@polinema.ac.id
}

(Artikel diterima: Februari 2020, direvisi: April 2020, diterima untuk terbit: Juli 2020)

\begin{abstract}
Abstrak - Komposit adalah suatu material yang terdiri dari campuran atau kombinasi dua atau lebih material baik secara mikro atau makro dimana sifat material tersebut berbeda bentuk dan komposisi kimia dari zat asalnya (Smith, 1996). Pada penelitian ini dilakukan pengujian fatigue terhadap komposit fiber metal untuk mengetahui laju rambatan retak sehingga dapat diketahui umur dari spesimen komposit fiber metal tersebut. Dengan variable bebas adalah orientasi sudut serat karbon dan kekasaran permukaan aluminium dengan respon variable terikatnya dalah laju rembatan retak. Pembuatan spesimen fiber metal laminates menggunakan metode Vacuum Resin Infuse. (VARI) yang menggunakan pompa vacuum sebagai alat untuk meengalirkan resin dari reservoir ke cetakan. Metode ini digunakan untuk meminimalisir terjadinya gelembunug udara yang terjebak pada spesimen yang menyebabkan terjadinya cacat porositas yang akan menurunkan kekuatan spesimen fiber metal laminates itu sendiri. Pengujian fatigue dilakukan dengan metode stress amplitude. Yaitu besar pembebanan saat uji tarik nilainya adalah sepertiga dari kekuatan tariknya. Setelah pengujian fatigue dilakukan, didapatkan hasil pada spesimen dengan orientasi sudut serat $0 / 90^{\circ}$, laju rambatan retak melambat dengan nilai siklus 90000 pada spesimen dengan nilai kekasaran permukaan 2,128 $\mu$ m kemudian mengalami penurunan siklus pada spesimen dengan nilai $2,887 \mu \mathrm{m}$ yaitu 11000 siklus.
\end{abstract}

Kata kunci: Fiber Metal Laminated Composite, Fatigue, Laju rambatan retak, Kekasaran Permukaan.

\section{Pendahuluan}

Pada perkembangan dalam bidang material teknik, kebanyakan logam diolah menjadi peralatan rumah tangga, peralatan makan dan minum, ornamen dan alat perang seperti pedang, baju tempur, dan tameng (shield) pada awal penemuan logam oleh umat manusia yaitu sekitar tahun 6000 SM (Cramb, 1996). Namun dengan berkembangnya ilmu dan teknologi, logam kemudian diolah untuk perindustrian. Industri otomotif merupakan salah satu bidang industri yang banyak menggunakan logam sebagai bahan baku produksinya. Seperti pada pembuatan rangka mobil, rangka motor, body mobil, suku cadang mobil dan motor dan komponen mesin- mesin kendaraan bermotor. Selain banyak digunakan pada industri otomotif, logam juga banyak digunakan sebagai bahan konstruksi bangunan. Pertahanan militer juga menjadi industri yang menggunakan logam sebagai bahan baku produksi, seperti pembuatan tank, Meriam, senapan, dan lain-lain.

Penggunaan logam untuk proses rekayasa dan industri memang cukup diminati sebagai bahan baku. Hampir semua industri menggunakan logam sebagai bahan baku, namun logam juga memiliki beberapa kekurangan untuk dijadikan sebagai material pada proses rekayasa dan industri. Kekurangan logam diantaranya yaitu bersifat korosif. Untuk mengatasi kekurangan logam yang bersifat korosif, akhir-akhir ini komposit menjadi material yang mulai banyak digunakan sebagai bahan baku produksi. Komposit yang memiliki sifat tahan korosi dan umumnya lebih ringan dari logam mulai banyak digunakan sebagai material pada industri dan proses rekayasa.

Komposit adalah material yang tersusun dari campuran dua atau lebih material yang memiliki sifat kimia dan sifat fisik yang berbeda yang nantinya menghasilkan material baru yang memiliki sifat berbeda dengan material penyusunnya (Ary,2015). Bahan penyusun dari komposit terdiri dari empat komponen, yaitu matrik, material penguat (reinforce), material pengisi (filler) dan material penambah (additive).

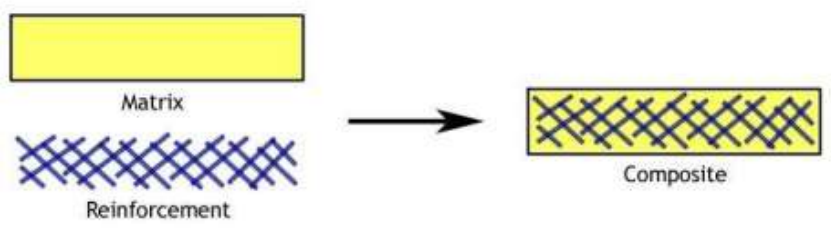

Gambar 1 Ilustrasi komposit

Serat karbon, grafit karbon atau CF adalah bahan yang terdiri dari serat yang sangat tipis sekitar 0,005-0,010 $\mathrm{mm}$ dan sebagian besar terdiri dari atom karbon. Atom karbon yang terikat bersama kristal mikroskopis yang sejajar dengan sumbu panjang serat. Hal ini yang membuat serat karbon merupakan serat yang sangat kuat untuk serat seukurannya. Beberapa ribu serat karbon dipintal bersama untuk membentuk sebuah benang, yang dapat digunakan dengan sendirinya atau ditenun menjadi kain. (Bregar \& Bill, 2017). Serat karbon memiliki banyak pola pintal yang berbeda dan dapat dikombinasikan dengan resin plastik dan dicetak untuk membentuk material komposit seperti plastik yang diperkuat serat karbon (CFRP) untuk membuat bahan yang memiliki strength-to-weight ratio tinggi. Densitas serat karbon juga lebih rendah daripada densitas dari baja, sehingga ideal untuk aplikasi yang memerlukan bahan yang ringan. Dari uraian tersebut menunjukkan serat karbon berpotensi sebagai penguat atau inti pada komposit.

Fatigue atau kelelahan menurut ASM (1975) didefinisikan sebagai proses perubahan struktur permanen progressive localized pada kondisi yang menghasilkan fluktuasi regangan dan tegangan dibawah kekuatan tariknya dan pada satu titik atau banyak titik yang dapat memuncak menjadi retak (crack) atau patahan (fracture) secara keseluruhan sesudah fluktuasi tertentu. Terdapat tiga fase dalam patahan fatigue yaitu;

a. Permulaan retak

Mekanisme fatik umumnya dimulai dari crack initiation yang terjadi di permukaan material yang 
lemah atau daerah dimana terjadi konsentrasi tegangan di permukaan (seperti goresan, notch, lubang-pits dll) akibat adanya pembebanan berulang.

b. Penyebaran retak

Crack initiation ini berkembang menjadi microcracks. Perambatan atau perpaduan microcracks ini kemudian membentuk macrocracks yang akan berujung pada failure.

c. Patah

Perpatahan terjadi ketika material telah mengalami siklus tegangan dan regangan yang menghasilkan kerusakan yang permanen.

Untuk mengetahui proses dari tiga fase di atas erlu dilakukan pengujian lelah atau fatigue test. Pengujian lelah dapat dipergunakan untuk melihat ketahanan suatu material terhadap pembebanan dinamik atau berulang dimana beban yang diberikan dibawah kekuatan luluhnya. Kekuatan lelah dipengaruhi oleh banyak variable, antara lain: ukuran spesimen, bentuk spesimen, pengerjaan akhir, jenis beban/tegangan. Dengan menggunakan variable beban atau tegangan maka menghasilkan siklus yang berbeda, sehingga dapat dibuat grafik S-N.

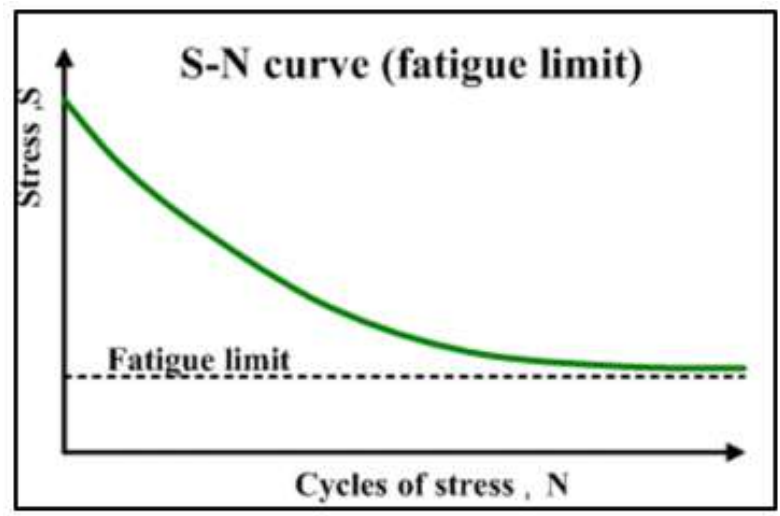

Gambar 2 Skema Kurva S-N

Pengujian fatigue umumnya dilakukan dengan pemberian tegangan atau beban dinamis uniaksial. Tegangan dinamis yang diberikan bervariasi, bisa tarik-tarik. Tarik-tekan dan tekan-tekan.

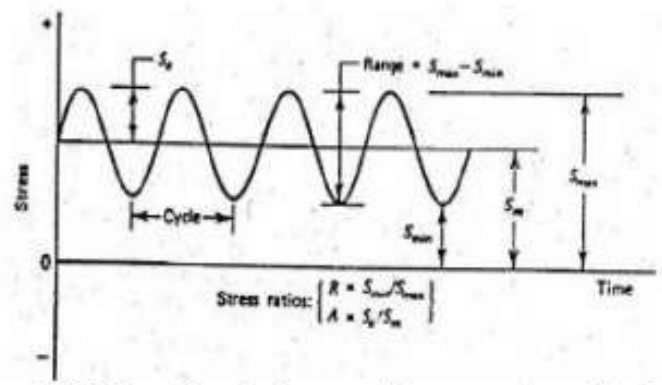

Gambar 3. Siklus Pembebanan Dengan Amplitude Konstan

Gambar 3 menunjukkan siklus tegangan tarik berulang dengan tegangan maksimum (S_max) dan tegangan minimum (S_min).

\section{- Metode Vacuum Assisted Resin Infusion}

Vacuum assisted resin infusion (VARI) adalah metode pembuatan material komposit yang menggunakan aplikasi tekanan rendah bertujuan untuk mengatur jalannya resin menjadi lamina. Material yang menjadi matriks diletakan disebuah cetakan, kemudian dilakukan proses vacuum untuk menarik aliran resin kedalam kedalam cetakan.

Metode VARI menghasilkan material komposit yang mempunyai rasio fiber- resin yang tinggi dibandingkan dengan metode hand lay-up. Metode hand lay-up menggunakan cara manual untuk mengalirkan resin, sedangka cn pada metode VARI aliran resin dilakukan oleh tekanan vacuum yang konstan. Penggunaan tekanan vacuum konstan ini yang mengatur distribusi resin agar tetap dalam suatu jumlah tertentu. Hal ini menyebabkan rasio fiberresin menjadi tinggi sehingga menghasilkan material komposit yang kuat dan ringan.

Beberapa langkah dasar dalam proses VARI adalah sebagai berikut:

Metode VARI diklasifikasikan menjadi dua jenis, yaitu metode Surface Infusion dan metode Interlaminar Infusion (Mack And Smith, 2003). Pada metode surface infusion, resin dialirkan melewati bagian permukaan lamina, dengan kerugian terbesar terdapat pada biaya yang disebabkan persiapan pengoperasian mesin, dan kompleksitas yang meningkat jika metode ini diaplikasikan untuk skala besar. Sedangkan pada metode interlaminar infusion, resin dialirkan melalui ruang antar lamina. Metode Interlaminar Infusion memiliki banyak keuntungan jika diaplikasikan dalam skala besar. Resin dialirkan diantara lamina sehingga ketebalan resin terjaga pada ruang antar lamina. Selain itu, proses pengaliran resin lebih cepat karena melewati ruang yang sudah dijaga ketebalannya. Proses yang lebih terjada ini juga menyebabkan material sisa yang terbuang semakin berkurang.

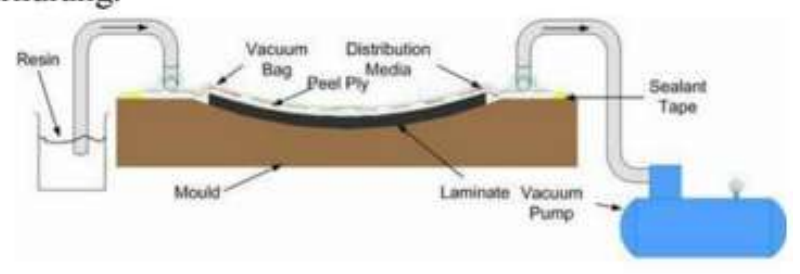

Gambar 4 Skema VARI Surface Infusion (a) dan (b) skema VARI Interlaminar Infusion 


\section{Metode penelitian}

Variabel Bebas:

Variabel bebas pada penelitian ini adalah orientasi sudut serat karbon dengan besarnya sudut serat adalah sebagai berikut:

1. $0 / 90^{\circ}$

2. $45 / 45^{\circ}$

Variasi kekasaran permukaan $(\mathrm{Ra})$ sebagau berikut:

1. Kekasaran $1 \quad: 1,675 \mu \mathrm{m}$

2. Kekasaran $2 \quad: 1,783 \mu \mathrm{m}$

3. Kekasaran $3: 1,936 \mu \mathrm{m}$

4. Kekasaran $4: 2,128 \mu \mathrm{m}$

5. Kekasaran $5 \quad: 2,887 \mu \mathrm{m}$

Variabel Terikat

Variabel terikat pada penelitian ini adalah sebagai berikut: Laju rambatan retak spesimen fiber metal laminates

Pembuatan Spesimen Komposit

Langkah pembuatan specimen uji sesuai dengan standar specimen uji tarik D638-03 dan uji fatigue ASTM D3479 menggunakan komposit laminat dengan metode vacuum sebagai berikut:

1. Menyiapkan bahan. (plat aluminium yang telah diberi keasaran permukaan, serat karbon yang telah dipotong, epoxy, hardener, dan peralatan pembuatan komposit dengan metode vacuum).

2. Melumasi alas / cetakan dengan grease agar specimen tidak lengket saat dilakukan pembongkaran.

3. Menyusun struktur FML komposit dengan susunan aluminium sebagai lapisan luar dan sebagai inti adalah komposit serat karbon dengan variasi sudut serat.

4. Menyiapkan flow media dan mesh dengan dimensi yang telah ditentukan.

5. Menata struktur FML pada alas dan dibungkus dengan vacuum bag.

6. Menyalakan pompa vaccum sebagai trial untuk memastikan tidak ada kebocoran pada vacuum bag, jika terjadi kebocoran maka tekanan pada pressure gauge akan turun

7. Menyiapkan resin epoxy dan hardener dengan perbandingan 2:1.
8. Jika sudah tidak ada kebocoran, selanjutnya mulai proses menghisap adonan resin kedalam vacuum bag yang telah disiapkan sebelumnya.

9. Pengeringan komposit pada suhu yang telah terisolasi dalam vacuum bag.

10. Setelah kering dapat dilakukan proses pembongkaran specimen yang telah dibuat.

11. Tahap pengamatan pada FML kompsit yang telah dibuat.
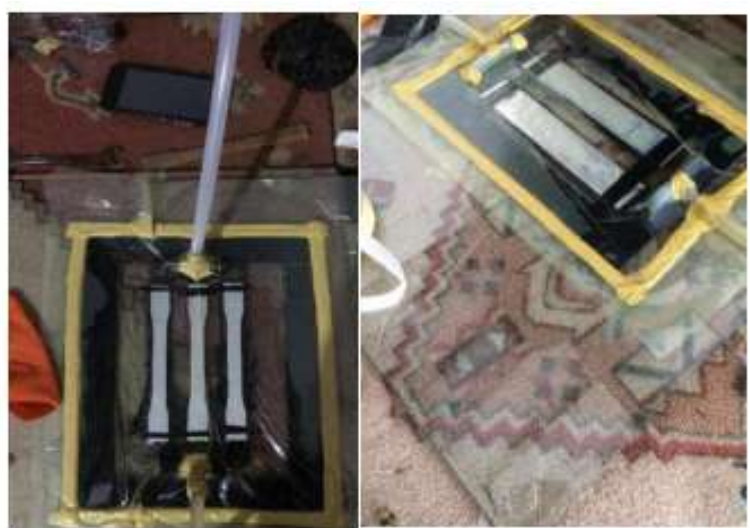

Gambar 5 Proses Pembuatan Komposit Dengan

Metode Vacuum Infusion

\section{Hasil dan Pembahasan}

\subsection{Pengujian Fatigue Spesimen Fiber Metal}

Lamiinates

Pengujian fatigue pada penelitian ini dilakukan bertujuan untuk mengamati laju perambatan retak spessimen fiber metal laminates tiap variasi kekasaran permukaan dan orientasi sudut serat. Dengan melakukan uji fatigue ini kita mendapatkan data banyaknya siklus spesimen fiber metal laminates tiap variasi kekasaran permukaan dan variasi orientasi sudut serat seperti pada table berikut:

Tabel 3.1 Data siklus hasil pengujian fatigue spesimen dengan orientasi sudut $0 / 90^{\circ}$

\begin{tabular}{|c|c|c|}
\hline $\begin{array}{c}\text { Kekasaran } \\
\text { Permukaan } \\
\left(R_{a}\right)(\mu \mathrm{m})\end{array}$ & $\begin{array}{c}\text { Displacement } \\
\text { Ratio }(\mathrm{R})\end{array}$ & Siklus \\
\hline 0,33 & 0 & 25000 \\
\hline 1,68 & 0 & 40000 \\
\hline 1,78 & 0 & 740000 \\
\hline 1,93 & 0 & 90000 \\
\hline 2,128 & 0 & 90000 \\
\hline 2,887 & 0 & 11000 \\
\hline
\end{tabular}

Hasil pengujian fatigue spesimen fiber metal laminatesdengan orientasi sudut serat $45 / 45^{\circ}$ ditunjukkan pada tabel berikut: 
Tabel 3.2 Data Siklus hasil pengujian fatigue spesimen dengan orientasi sudut serat $45 / 45^{\circ}$

\begin{tabular}{|c|c|c|}
\hline $\begin{array}{c}\text { Kekasaran } \\
\text { Permukaan } \\
\left(R_{a}\right)(\mu \mathrm{m})\end{array}$ & $\begin{array}{c}\text { Displacement } \\
\text { Ratio }(\mathrm{R})\end{array}$ & Siklus \\
\hline 0,33 & 0 & 440000 \\
\hline 1,68 & 0 & 40000 \\
\hline 1,78 & 0 & 25000 \\
\hline 1,93 & 0 & 4000 \\
\hline 2,128 & 0 & 7000 \\
\hline 2,887 & 0 & 60000 \\
\hline
\end{tabular}

Selain untuk mengetahui data banyaknya siklus tiap spesimen fiber metal laminates, pengujian ini juga bertujuan untuk mengetahui perambatan retak spesimen tiap variasi kekasaran permukaan dan orientasi sudut serat. Untuk mengetahui laju perambatan retak spesimen fiber metal laminates dapat dilihat pada contoh data berikut:

Tabel 3.3 Data jumlah siklus dan panjang retak hasil pengujian fatigue

\begin{tabular}{|c|c|c|c|}
\hline \multirow{2}{*}{ Jumlah Siklus } & \multicolumn{2}{|c|}{$\begin{array}{c}\text { Panjang retak } \\
\text { (mm) }\end{array}$} & $\begin{array}{c}\text { Jumlah } \\
\text { panjang retak } \\
\text { rata-rata (mm) }\end{array}$ \\
\cline { 2 - 3 } & Kiri & Kanan & 4,377 \\
\hline 5000 & 1,247 & 1,507 & 5,3255 \\
\hline 10000 & 2,207 & 2,444 & 5 \\
\hline
\end{tabular}

Pada pengujian fatigue intinya adalah untuk mengetahui laju rambatan retak spesimen dengan beban kecil namun berulang, atau suatu material dikenai pembebanan secara siklik. Kemudian pada kedua sisi notch diukur dan dihitung panjang retak rata-rata (a).

Untuk mengetahui panjang retak rata-rata (a) tiap siklus saat dilakukan pengujian dapat dihitung dengan rumus berikut.

$$
\begin{aligned}
a=\frac{\Sigma \text { panjang notch }+\Sigma \text { panjang retak }}{2} \\
=\frac{(3+3)+(1,247+1,507)}{2} \\
=4,377 \mathrm{~mm}
\end{aligned}
$$

Kemudian untuk mengetahui laju laju perambatan retak $(\mathrm{da} / \mathrm{dN})$ tiap siklus saat pengujian dapat dihitung menggunakan rumus berikut. (contoh perhitungan diambil pada sikus 10000 )

$$
\begin{array}{r}
\frac{d a}{d N}=\frac{a_{n}-a_{n-1}}{N_{n}-N_{n}-1}=\frac{5,3255-4,377}{10000-5000} \\
=0,0001897 \mathrm{~mm} / \text { siklus }
\end{array}
$$

Jadi untuk laju rambatan retak $(\mathrm{da} / \mathrm{dN})$ pada siklus ke 10000 spesimen fiber metal laminates saat pengujian Lelah / fatigue yaitu $0,0001897 \mathrm{~mm} / \mathrm{siklus}$. Begitupun juga untuk beberapa siklus lainnya dapat dihitung dengan metode yang sama untuk mengetahui laju perambatan retaknya.

\subsection{Pengaruh Kekasaran Permukaan dan Orientasi Sudut Serat 0/90 ${ }^{\circ}$}

Pembahasan pada penelitian ini difokuskan pada pengaruh kekasaran permukaan aluminium dan orientasi sudut serat karbon terhadap laju perambatan retak pada spesimen fiber metal laminates. Untuk mengetahui pengaruh kekasaran permukaan dan orientasi sudut serat sebesar $0 / 90^{\circ}$ terhadap laju perambatan retak dapat dilihat pada gambar berikut:

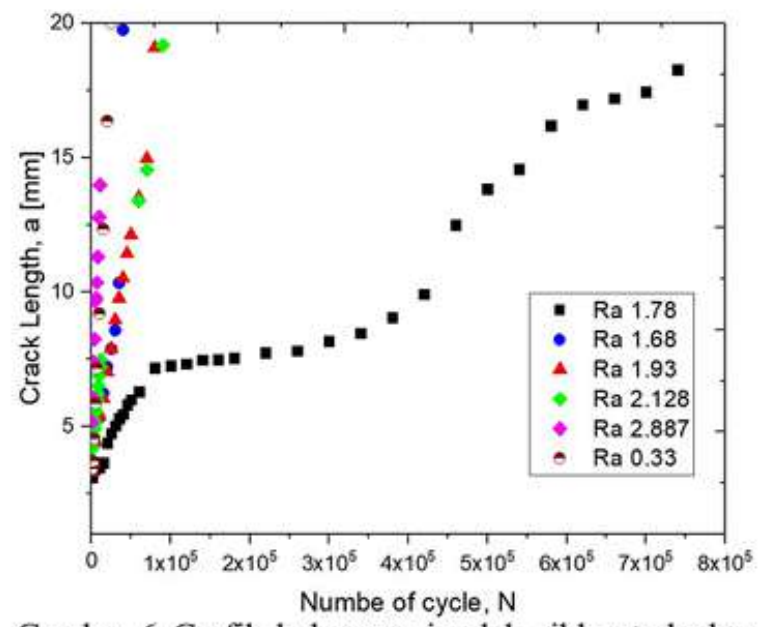

Gambar 6 Grafik hubungan jumlah siklus terhadap panjang retak spesimen fiber metal laminates tiap variasi kekasaran permukaan $\left(R_{a}\right)$ dan orientasi sudut serat $0 / 90^{\circ}$

Grafik pada gambar 6 menjelaskan hubungan jumlah siklus terhadap panjang retak spesimen fiber metal laminates tiap variasi kekasaran permukaan $(\mathrm{Ra})$ dengan orientasi sudut serat $0 / 90^{\circ}$. Pada grafik tersebut dapat diamati spesimen denga nilai $R$ a0 $033 \mu \mathrm{m}$ patah pada siklus 25000 , spesimen dengan nilai $\mathrm{Ra} 1,68 \mu \mathrm{m}$ patah pada siklus 40000 kemudian spesimen dengan nilai $\mathrm{Ra} 1,93 \mu \mathrm{m}$, $\mathrm{Ra}$ $2,128 \mu \mathrm{m}$ dan $\mathrm{Ra} 2,887 \mu \mathrm{m}$ umur spesimen mengalami penurunan ditandai dengan semakin turunnya jumlah siklus pada spesimen fiber metal laminates. Spesimen dengan nilai Ra 1,93 $\mu \mathrm{m}$ patah pada siklus 90000 , spesimen dengan nilai nilai $\mathrm{Ra}$ $2,887 \mu \mathrm{m}$ patah pada siklus 11000 . Pada penelitian ini selain untuk mengetahui hubungan jumlah siklus terhadap panjang retak juga dilakukan pengamatan bagaimana pengaruh kekasaran permukaan $(\mathrm{Ra})$ dan orientasi sudut serat $0 / 90^{\circ}$ terhadap laju rambatan retak spesimen fiber metal laminates yang ditunjukkan pada gambar berikut. 


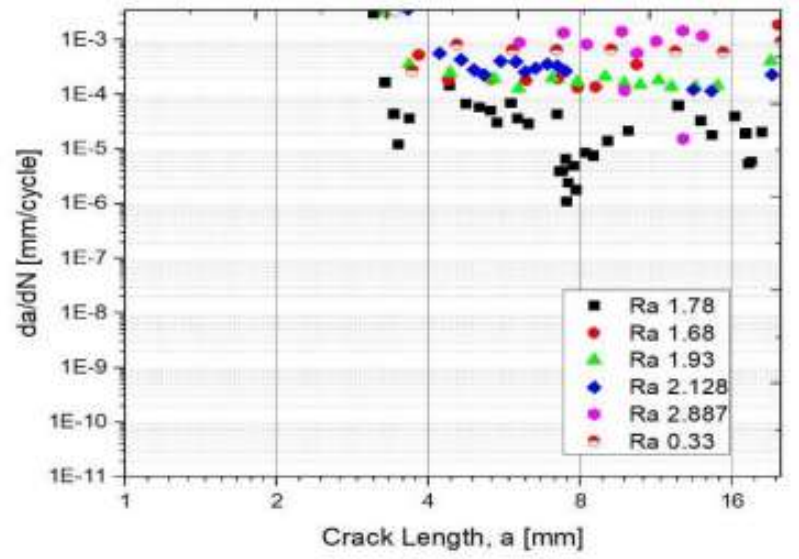

Gambar 7 Grafik hubungan panjang retak rata-rata (a) terhadap laju rambatan retak $(\mathrm{da} / \mathrm{dN})$ spesimen fiber metal laminates dengan orientasi sudut $0 / 90^{\circ}$

Gambar 7 menjelaskan hubungan panjang retak rata-rata (a) terhadap laju perambatan retak $(\mathrm{da} / \mathrm{dN})$ spesimen fiber metal laminates tiap variasi kekasaran permukaan $(\mathrm{Ra})$ dengan orientasi sudut serat $0 / 90^{\circ}$. Selain menurunnya umur spesimen, kekasaran permukaan juga mempengaruhi laju rambatan retak spesimen fiber metal laminates. Spesimen fiber metal laminates dengan nilai $\mathrm{Ra} 0,33$ $\mu \mathrm{m}, \mathrm{Ra} 1,68 \mu \mathrm{m}$, Ra $1,78 \mu \mathrm{m}$, semakin tinggi nilai kekasaran permukaan laju perambatan retak mengalami penurunan, namun pada spesimen fiber metal laminates dengan nilai $\mathrm{Ra} 1,93 \mu \mathrm{m}$ sampai $\mathrm{Ra}$ $2,887 \mu \mathrm{m}$ laju perambatan retak justru semakin cepat.

Dengan menggunakan metode stress amplitude pada pengujian fatigue menghasilkan pembebanan yang diterima spesimen berantung pada nilai kekuatan tarik tiap variasi kekasaran permukaan. Hal ini menjadi dasar menentukan nilai pembebanan saat pengujian fatigue dilakukan. Nilai pembebanan fatigue dapat ditentukan dengan rumus berikut.

$$
\text { Load }=\frac{1 / 3 \times \text { uts } x A}{2}
$$

Dengan:
Uts
: Ultimate Tensile Strength
A : Luas Penampang

Nilai pembebanan pada saat pengujian fatigue spesimen fiber metal laminates berdasarakan rumus menghitung beban fatigue dapat dilihat pada table berikut.
Tabel 3.3 Nilai pembebanan uji fatigue spesimen tiap variasi $R_{a}$ orientasi sudut serat $0 / 90^{\circ}$

\begin{tabular}{|c|c|c|c|}
\hline $\begin{array}{c}\text { Kekasaran } \\
\text { Permukaan } \\
(\mathrm{Ra})(\mu \mathrm{m})\end{array}$ & $\begin{array}{c}\text { Ultimate } \\
\text { Tensile } \\
\text { Strength } \\
(\mathrm{MPa})\end{array}$ & $\begin{array}{c}\text { Load } \\
(\mathrm{kN})\end{array}$ & $\begin{array}{c}\text { Jumlah } \\
\text { Siklus }\end{array}$ \\
\hline 0,33 & 195,8 & 1,3 & 25000 \\
\hline 1,68 & 199,1 & 1,36 & 40000 \\
\hline 1,78 & 253,4 & 1,7 & 740000 \\
\hline 1,93 & 265,8 & 1,8 & 90000 \\
\hline 2,128 & 271,4 & 1,86 & 90000 \\
\hline 2,887 & 282,3 & 1,9 & 11000 \\
\hline
\end{tabular}

Tabel 3.3 menunjukkan bahwa semakin tinggi nilai $\mathrm{Ra}$ maka semakin tinggi juga nilai kekuatan tariknya begitupula semakin tinggi juga pembebanan saat pengujian fatigue dilakukan. Jumlah siklus saat pengujian meningkat untuk spesimen dengan nilai $\mathrm{Ra} 0,33 \mu \mathrm{m}, \mathrm{Ra} 1,68 \mu \mathrm{m}$ dan $\mathrm{Ra} 1,78 \mu \mathrm{m}$ dengan nilai pembebanan secara berurutan $1,3 \mathrm{kN}, 1,36 \mathrm{kN}$ dan $1,7 \mathrm{kN}$. Kemudian untuk spesimen dengan nilai R_a $1,93 \mu \mathrm{m}, \mathrm{Ra} 2,128$ $\mu \mathrm{m}$ dan $\mathrm{Ra} 2,887 \mu \mathrm{m}$ dengan nilai pembebanan diatas

$1,7 \mathrm{kN}$ jumlah siklus justru mengalami penurunan. Nilai pembebanan yang terlalu tinggi mempengaruhi spesimen fiber metal laminates. Nilai pembebanan yang terlalu tinggi membuat umur material semakin rendah dengan ditandai semakin menurunnya jumlah siklus saat pengujian fatigue dan tingginya laju rambatan retak

\subsection{Pengaruh Kekasaran permukaan dan Orientasi Sudut Serat $\mathbf{4 5} / \mathbf{4 5}^{\circ}$}

Dua variable orientasi sudut serat digunakan pada penelitian ini, yaitu orientasi sudut serat $0 / 90^{\circ}$ dan $45 / 45^{\circ}$. Untuk mengetahui pengaruh kekasaran permukaan dan orientasi sudut serat $45 / 45^{\circ}$ terhadap pertumbuhan retak spesimen fiber metal laminates ditunjukkan pada gambar 5.3 berikut.

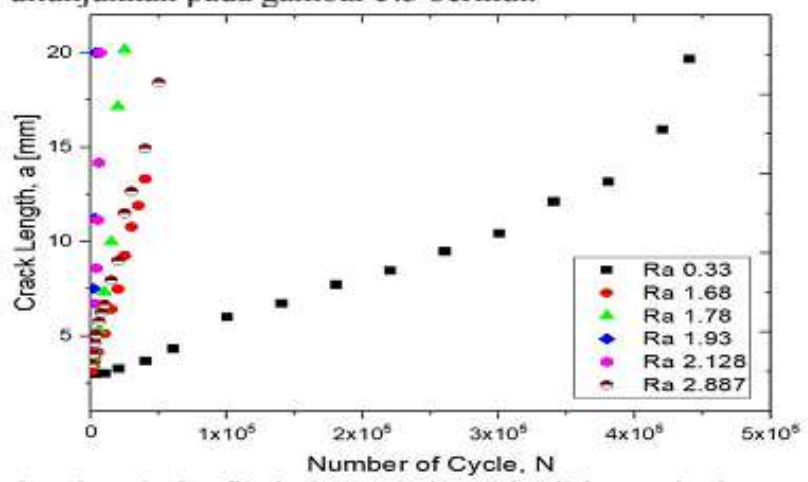

Gambar 8 Grafik hubungan jumlah siklus terhadap panjang retak spesimen fiber metal laminates tiap variasi kekasaran permukaan (R_a) dan orientasi sudut $45 / 45^{\circ}$ 
Gambar 9 menjelaskan hubungan panjang retak rata-rata (a) terhadap laju perambatan retak $(\mathrm{da} / \mathrm{dN})$ spesimen fiber metal laminates tiap variasi kekasaran permukaan ( $\mathrm{Ra}$ ) dengan orientasi sudut serat $45 / 45^{\circ}$. Variasi kekasaran permukaan pada penelitian ini mempengaruhi laju perambtaan retak spesimen fiber metal laminates. Pada spesimen fiber metal laminates dengan oreintasi sudut serat $45 / 45^{\circ}$, semakin tinggi nilai kekasaran permukaan atau semakin kasarnya permukaan aluminium laju rembatan retak kecenderungannya justru semakin meningkat. Kemudian pada spesimen dengan nilai kekasaran permukaan $2,887 \mu$ m nilai laju perambatan retaknya berada di bawah spesimen dengan nilai kekasaran permukaan $1,93 \mu \mathrm{m}$ dan Ra 2,128 $\mu \mathrm{m}$. Hal ini terjadi karena nilai pembebanan saat uji fatigue disamakan nilainya dengan pembebanan spesimen dengan kekasaran permukaan 2,887 $\mu \mathrm{m}$ dengan orientasi sudut serat $0 / 90^{\circ}$. Ini dilakukan karena jika nilia pembebanan disesuaikan dengan nilai pembebanan yang sesungguhnya pada spesimen dengan kekasaran permukaan $2,887 \mu \mathrm{m}$ dan orientasi sudut $45 / 45^{\circ}$ laju perambatan retak akan susah diamati karena data yang terekam sedikit disebabkan nilai pembebanannya terlalu besar.

Nilai pembebanan pada saat uji fatigue spesimen fiber metal laminates dengan orientasi sudut serat $45 / 45^{\circ}$ berdasarkan rumus untuk menghitung nilai pembebanan yang telah dibahas sebelumnya dapat dilihat pada tabel berikut.

Tabel 3.4 Nilai pembebanan saat uji fatigue spesimen tiap variasi $\mathrm{Ra}$ orientasi sudut $45 / 45^{\circ}$

\begin{tabular}{|c|c|c|c|}
\hline $\begin{array}{c}\text { Kekasaran } \\
\text { Permukaan } \\
(\mathrm{Ra})(\mu \mathrm{m})\end{array}$ & $\begin{array}{c}\text { Ultimate } \\
\text { Tensile } \\
\text { Strength } \\
(\mathrm{MPa})\end{array}$ & $\begin{array}{c}\text { Load } \\
(\mathrm{kN})\end{array}$ & $\begin{array}{c}\text { Jumlah } \\
\text { Siklus }\end{array}$ \\
\hline 0,33 & 72,4 & 0,4 & 440000 \\
\hline 1,68 & 187,3 & 1,2 & 40000 \\
\hline 1,78 & 210 & 1,4 & 25000 \\
\hline 1,93 & 357 & 2,4 & 4000 \\
\hline 2,128 & 361 & 2,47 & 7000 \\
\hline 2,887 & 282,3 & 1,9 & 60000 \\
\hline
\end{tabular}

Pada tabel 3.4 dapat diamati bahwa semakin tinggi nilai kekasarran permukaan yaitu spesimen dengan nilai $\mathrm{Ra} 0,33 \mu \mathrm{m}$ sampai $\mathrm{Ra} 2,128 \mu \mathrm{m}$ maka semakin tinggi pula nilai kekuatan tariknya yang menyebabkan semakin tinggi juga nilai pembebanan saat pengujian fatigue dilakukan. Semakin tinggi nilai Ra pada spesimen dengan orientasi sudut serat $45 / 45^{\circ}$ umur spesimen justru semakin rendah, hal ini disebabkan pembebanan yang diberikan pada spesimen juga semakin besar. Pembebanan yang terlalu besar dapat mempengaruhi spesimen fiber metal laminates yang berpengaruh semakin rendah umur material dengan ditandai semakin menurunnya nilai siklus saat pengujian fatigue dan tingginya laju perambatan retak yang terjadi. Namun pada spesimen dengan nilai $\mathrm{Ra} 2,887 \mu \mathrm{m}$ sikllus mengalami kenaikan dengan nilai 60000 siklus dikarenakan pada saat pengujian ini pembebanan disesuaikan dengan nilai pembebanan spesimen $\mathrm{Ra} 2,887 \mu \mathrm{m}$ dengan orientasi sudut serat $0 / 90^{\circ}$. Karena jika pembebanan yang diberikan disesuaikan dengan nilai pembebanan sesungguhnya pada spesimen Ra 2,887 $\mu \mathrm{m}$ dengan orientasi sudut serat $45 / 45^{\circ}$ yaitu sebesar $2,5 \mathrm{kN}$ laju perambatan retak tidak bisa diamati karena data yang terekam sedikit.

Penerapan stress amplitude berdasarkan hasil penelitian ini kurang sesuai jika diterapkan pada komposit. Stress amplitude kemungkinan dapat diterapkan pada material yang memiliki siklus fatigue yang tinggi atau high cycle fatigue yang dikarenakan keuletan material tersebut sehingga sesuai dalam penerapan stress amplitude. Pada perambatan retak, awal terjadi retakan atau crack initiation terjadi pada material yang mudah terdeformasi plastis atau material dengan kekuatan rendah, setelah itu retak merambat sampai material mengalami patah atau kegagalan. Pada penelitian ini penggunaan stress amplitude kemungkinan sesuai jika niilai pembebanan disesuaikan dengan material yang memiliki kekuatan tarik terendah, yaitu aluminium saja tanpa penguat karbon.

\subsection{Delaminasi Pada Spesimen Uji Fatigue Fiber Metal Laminates}

Delaminasi adalah model kegagalan pada material baja atau komposit yanng berstruktur lamina atau lapis. Kegagalan ini disebabkan oleh bermacammcam hal, misalnya beban siklik yang berulang, tumbukan (impact)nataupun pengaruh lainnya yang menyebabkan antar lapisan terpisah (WJ Cantwell \& J Morton, 1991). Lapisan yang mudah terpisah mampu mengurangi ketangguhan suatu material secara signifikan. Delaminasi juga bias terjadi karena lemahnya ikatan antar serat dan matrik, selain itu kemampuan matrik mengisi ruang antar serat juga mempengaruhu delaminasi.

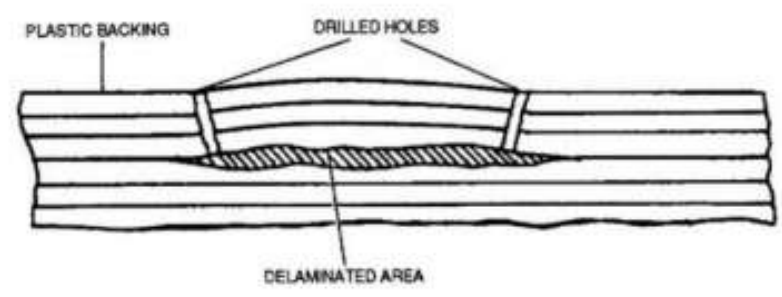

Gambar 10 Delaminasi pada komposit

Pada penelitian ini delaminasi mempengaruhi ikatan antar lapisan aluminium dan komposit serat karbon pada spesimen fiber metal laminates. Ikatan antar lapisan ini juga mempengaruhi sifat mekanik spesimen fiber metal laminates. Untuk mendeteksi adanya delaminasi pada spesimen diperlukan suatu pengamatan mengenai 
luas area delaminasi yang terjadi pada spesimen. Semakin luas area delaminasi kekuatan spesimen menjadi rendah begitu juga sebaliknya.

Luas area delaminasi yang terjadi pada spesimen uji fatigue metal laminates juga diamati pada penelitian ini. Untuk mengetahui delaminasi yang terjadi pada spesimen uji fatigue, spesimen yang telah diuji fatigue dicelupkan ke dalam tinta, kemudian luas area diamati dengan bantuan software ImageJ. Gambar area delaminasi yang terjadi pada spesimen uji fatigue dapat dilihat pada gambar berikut. (sample gambar delaminasi yang diukur menggunakan software ImageJ pada spesimen FML dengan orientasi sudut $0 / 90^{\circ}$ )

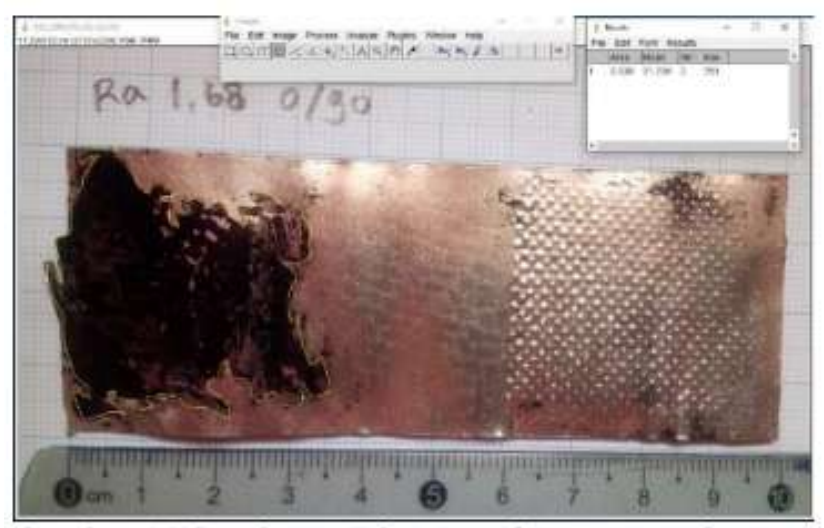

Gambar 11 Spesimen Fiber Metal Laminates dengan nilai $\mathrm{Ra} 1,68 \mu \mathrm{m}$

Untuk mengetahui luas area delaminasi yang terjadi pada spesimen diukur menggunakan bantuan software ImageJ. Hasil pengukuran luas area delaminasi pada spesimen uji fatigue menggunakn software ImageJ dapat dilihat pada table berikut.

Tabel 3.5 Luas area delaminasi spesimen dengan orientasi sudut serat $0 / 90^{\circ}$

\begin{tabular}{|c|c|}
\hline $\begin{array}{c}\text { Kekasaran Permukaan } \\
(\mathrm{Ra})(\mu \mathrm{m})\end{array}$ & $\begin{array}{c}\text { Luas Area Delaminasi } \\
\left(\mathrm{cm}^{2}\right)\end{array}$ \\
\hline 0,33 & 1,078 \\
\hline 1,68 & 1,3 \\
\hline 1,78 & 2,2 \\
\hline 1,93 & 2,25 \\
\hline 2,128 & 2,78 \\
\hline 2,887 & 5,2 \\
\hline
\end{tabular}

Untuk melihat kecenderungan bagaimana pengaruh kekasaran permukaan terhadap luas area delaminasi dapat dilihat pada grafik berikut.
Grafik Hubungan Kekasaran Permukaan Terhadap Luas Area Delaminasi

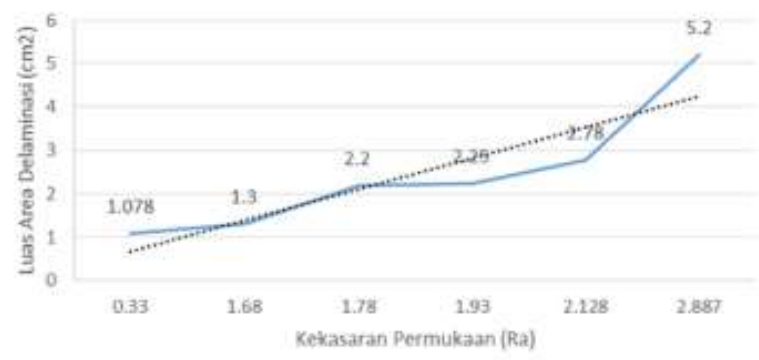

Gambar 12 Hubungan kekasaran permukaan terhadap luas area delaminasi spesimen fiber metal laminates dengan orientasi sudut serat $0 / 90^{\circ}$

Selain mengamati luas area delaminasi spesimen dengan orientasi sudut $0 / 90^{\circ}$, penelitian ini juga mengamati luas area delaminasi spesimen dengan oruentasi sudut serat $45 / 45^{\circ}$. Berikut adalah gambar area delaminasi yang terjadi pada spesimen dengan orientasi sudut serat $45 / 45^{\circ}$. (sample gambar delaminasi yang diukur menggunakan software ImageJ)

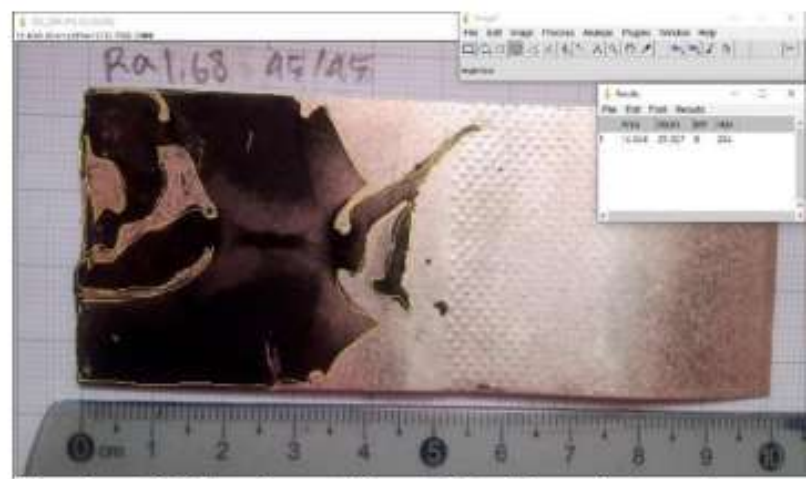

Gambar 13 Spesimen Fiber Metal Laminates dengan nilai $\mathrm{Ra} 1,68 \mu \mathrm{m}$

Untuk mengetahui luas area delaminasi yang terjadi pada spesimen diukur menggunakan bantuan software ImageJ. Hasil pengukuran luas area delaminasi pada spesimen uji fatigue menggunakan software ImageJ dapat dilihat pada table berikut.

Tabel 3.6 Luas area delaminasi spesimen dengan orientasi sudut serat $45 / 45^{\circ}$

\begin{tabular}{|c|c|}
\hline $\begin{array}{c}\text { Kekasaran Permukaan } \\
(\mathrm{Ra})(\mu \mathrm{m})\end{array}$ & $\begin{array}{c}\text { Luas Area Delaminasi } \\
\left(\mathrm{cm}^{2}\right)\end{array}$ \\
\hline 0,33 & 1,76 \\
\hline 1,68 & 14,5 \\
\hline 1,78 & 15,4 \\
\hline 1,93 & 16,6 \\
\hline 2,128 & 19,3 \\
\hline 2,887 & 22,6 \\
\hline
\end{tabular}


Untuk melihat kecenderungan bagaimana pengaruh kekasaran permukaan terhadap luas area delaminasi dapat dilihat pada grafik berikut:

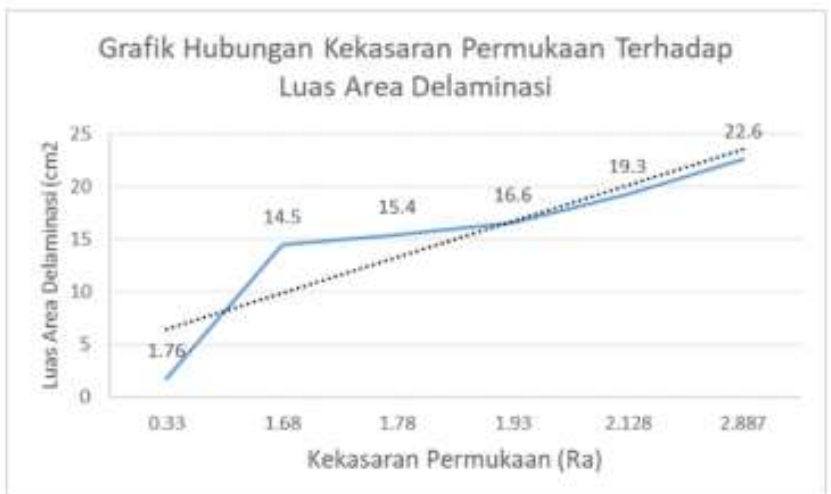

Gambar 14 Hubungan kekasaran permukaan terhadap luas area delaminasi spesimen fiber metal laminates dengan orientasi sudut serat $45 / 45^{\circ}$

Dari hasil pengukuran luas area delaminasi pada spesimen uji fatigue fiber metal laminates menggunakan software ImageJ, dapat dilihat semakin tinggi nilai $\mathrm{Ra}$ atau semakin kasar permukaan aluminium maka luas area delaminasi yang terjadi semakin meningkat baik pada orientasi sudut serat $0 / 90^{\circ}$ dan $45 / 45^{\circ}$. Ini terjadi dikarenakan semakin tinggi nilai $\mathrm{Ra}$ maka pembebanan yang diberikan pada spesimen uji fatigue juga semakin besar. Semakin besar pembebanan saat pengujian fatigue dapat melemahkan ikatan antara permukaan aluminium dan komposit serat karbon. Semakin lemah ikatan antar lapisan maka area delaminasi yang terjadi akan semakin luas.

\section{Kesimpulan dan Saran}

Kekasaran permukaan (Ra) mampu mempengaruhi laju perambatan retak spesimen fiber metal laminates. Semakin tinggi nilai Ra maka laju perambatan retak juga semakin meningkat. Ini terjadi karena nilai pembebanan saat uji fatigue adalah $1 / 3$ dari nilai tegangan tarik spesimen FML. Semakin tinggi nilai Ra maka kekuatan tariknya juga semakin meningkat sehingga nilai pembebanan saat uji fatigue dilakukan juga semakin tinggi sehingga menyebabkan semakin tinggi nilai kekasaran permukaan maka laju rambatan retak juga semakin meningkat.

Beredasarkan penelitian yang telah dilakukan ada beberapa saran yang dapat dilakukan pada penelitian selanjutnya, yaitu untuk memberikan perlakuan kekasaran permukaan dapat dilakukan dengan metode yang berbeda selain proses sand blasting dan pada saat pengujian fatigue dilakukan penerapan stress amplitude dapat diganti dengan displacement amplitude untuk memberikan hasil penelitian yang berbeda.

\section{DAFTAR PUSTAKa}

[1] Begum \& A.M. Islam (2013). Natural As A Substitute To Synthetic Fiber In Polymer Composites, Review, Research Journal Of Engineering Science Vol.2 (3), 46-53

[2] Book Standard ASTM D638-03 (2003). Standard Test Method For Tensile Properties Of Plastics. ASTM International

[3] Gibson. R.F. (1994). Principle Of Composite Of Mechanical Engineering, Wayne State University Detroit, Michigan, Mc Graw-Hill, Inc

[4] Pizzi, A. (1994) Advanced Wood Adhesives Technology. Marcel Dekker, inc. New Yok.

[5] Tata S. \& Saito S. (1995). Pengetahuan Bahan Teknik Akbulut Mustafa and Sonmez O. Fazil. 2011. Design Optimation of Laminated Composites Using a New Variant of Simulated Annealing, Department of Mechanical Engineering Bogazici University, Istanbul, Turki

[6] Subagia Ary I.D.G. 2015. Studi Eksperimen Sifat Mekanis Hibrid Komposit Epoxy Dengan Penguat Serat Karbon 